\title{
Chemical Composition, Fiber Morphology, and Kraft Pulping of Bracken Stalks (Pteridium aquilinum (L.) Kuhn)
}

\section{Kemijski sastav, morfologija vlakana i sulfatni postupak proizvodnje celuloze od stabljika paprati (Pteridium aquilinum (L.) Kuhn)}

\author{
Original scientific paper • Izvorni znanstveni rad \\ Received-prispjelo: 12. 4. 2017. \\ Accepted-prihvaćeno: 21. 2. 2018. \\ UDK: $630 * 861.311 ; 630 * 862.1$; \\ doi:10.5552/drind.2018.1725
}

\begin{abstract}
In this study, kraft, kraft-NaBH$H_{4}$ and kraft- $\mathrm{KBH}_{4}$ pulp and paper properties of the bracken stalks (Pteridium aquilinum (L.) Kuhn) were determined. Also, the chemical composition and fiber properties of bracken stalks were evaluated. $\mathrm{NaBH}_{4}$ and $\mathrm{KBH}_{4}$ were separately added to cooking liquor by $0.5 \%, 1 \%, 1.5 \%$, and $2 \%$ (oven dried wood). The boron compound-free kraft pulp were also made as control pulp. Fiber length and fiber width of bracken stalks were determined as $1.25 \mathrm{~mm}$ and $24 \mu \mathrm{m}$, respectively. Bracken stalks are composed of $73.34 \%$ holocellulose, $32.55 \% \alpha$-cellulose, and $30.79 \%$ lignin. In addition, the pulp yield was increased with additions of both boron compounds, while kappa number was decreased. Also, highest strength increases determined in $0.5 \% \mathrm{NaBH}_{4}$ added pulp. These results showed that bracken stalks can be used as a raw material for kraft pulp production.
\end{abstract}

Keywords: bracken, $\mathrm{KBH}_{4}$, kraft, $\mathrm{NaBH}_{4}$, Pteridium aquilinum (L.) Kuhn., paper properties

\begin{abstract}
SAŽETAK • U radu su opisana istraživanja svojstava kraft, kraft-NaBH $\mathrm{H}_{4} \mathrm{kraft}-\mathrm{KBH}_{4}$ celuloze $\mathrm{i}$ papira proizvedenih od stabljika paprati (Pteridium aquilinum (L.) Kuhn). Ocijenjeni su kemijski sastav i svojstva vlakana stabljika paprati. Otopini za kuhanje odvojeno su dodavani $\mathrm{NaBH}_{4}$ i $\mathrm{KBH}_{4}$ u postotcima 0,5; 1; 1,5 i $2 \%$ (u odnosu prema apsolutno suhom drvu). Kraft celuloza bez spojeva bora proizvedena je kao kontrolni uzorak. Duljina vlakana stabljika paprati iznosila je 1,25 mm, a širina 24 нm. Stabljike paprati sadržavaju 73,34\% holoceluloze, 32,55\% a-celuloze i 30,79\% lignina. Rezultati su pokazali da je uz dodatak obaju spojeva bora prinos celuloze povećan, dok je Kapa broj smanjen. Usto, rezultati su pokazali najveće povećanje čvrstoće za celulozu dobivenu dodatkom 0,5\% $\mathrm{NaBH}_{4}$. Na temelju dobivenih rezultata može se zaključiti da se stabljike paprati mogu upotrebljavati kao sirovina za proizvodnju kraft celuloze.
\end{abstract}

Ključne riječi: paprat, $\mathrm{KBH}_{4}$, sulfatni postupak, $\mathrm{NaBH}_{4}$, Pteridium aquilinum (L.) Kuhn., svojstva papira

\footnotetext{
Authors are associated professor and M.Sc. at Faculty of Forestry, Forest Products Engineering, Bartin University, Bartin, Turkey.

Autori su izvanredni profesor i magistar znanosti Sveučilišta u Bartinu, Šumarski fakultet, Odjel za industrije na bazi šuma, Bartin, Turska.
} 


\section{INTRODUCTION}

1. UVOD

Bracken (Pteridium aquilinum (L.) Kuhn), a weed with a height of $30-200 \mathrm{~cm}$, is the fifth most distributed common weed species of the world. Bracken is widely distributed from the Equator to the northern parts of Europe, in Central Asia, China and Japan, from central South America to subarctic Canada. It can easily grow and spread on many types of soil (Vetter, 2009).

Lignocellulosic biomass are included in wood and non-wood biomass. Wood-based lignocellulosic biomass, main raw material of pulp production, consists of hardwood and softwood species. Non-wood lignocellulosic biomass, such as wheat straw, rice straw, cotton stalks, canola stalks, sugarcane bagasse, switchgrass and reed, has been an important fiber resource for pulp production in countries with a shortage of wood raw material. The main differences between woody and non-wood lignocellulosic biomasses are their chemical compositions and physical properties (Zhu and Pan, 2010). The usability of a raw material in pulp production initially depends on these properties.

Global paper and paperboard production in 2000 and 2015 was 324.6 million ton and 406.3 million ton, respectively (FAOSTAT, 2016). Increasing paper production causes the decrease in forest resources. Non-wood lignocellulosic biomass is abundantly available, low cost, and easy to process. Also, it has a short growth and harvest period. For this reason, it is introduced as a potential raw material for pulp and paper production (Tye et al., 2016). However, in 2015, pulp production from non-wood lignocellulosic biomass was only 12.3 million ton (FAOSTAT, 2016). Many studies have examined the utilization of alternative raw materials in the pulp and paper industry. The utilization as an alternative raw material in paper industry of fruit trees, such as orange tree pruning (Gonzáléz et al., 2011), olive tree pruning (Requejo et al., 2012), pomegranate tree pruning (Gülsoy et al., 2015), white mulberry (Gençer et al., 2013), common hazelnut (Gençer and Özgül, 2016), wild cherry (Gençer and Gül Türkmen, 2016), was previously evaluated. On the other hand, pulp and paper properties of many non-wood plant species were determined by several authors (Deniz et al., 2004; Shatalov and Pereira, 2006; Çöpür et al., 2007; Akgül and Tozluoğlu, 2009; Shakhes et al., 2011; Gençer, 2015; Gençer and Şahin, 2015). However, there is no published report on using bracken stalks in pulp and paper production. The aim of this study was to evaluate the suitability of bracken stalks for papermaking. For this purpose, the kraft, kraft$\mathrm{NaBH}_{4}$, and kraft-KBH pulp properties of bracken stalks were evaluated. The chemical composition and fiber morphology of bracken stalks (Pteridium aquilinum (L.) Kuhn) were also determined.

\section{MATERIALS AND METHODS 2. MATERIJALI I METODE}

\subsection{Plant material and sample preparation}

2.1. Biljni materijal i priprema uzoraka

The bracken (Pteridium aquilinum (L.) Kuhn) were collected from the Bartin province of Turkey. The roots and leaves of bracken were removed and only the stalks were used. The stalks were chopped to $3-5 \mathrm{~cm}$. Bracken stalks were air-dried and stored in dry conditions.

\subsection{Chemical analysis}

2.2. Kemijska analiza

The standard methods were used in the main chemical analyses of bracken. The sample preparation (TAPPI T 257), holocellulose (Wise and Karl, 1962), $\alpha$-cellulose (Han and Rowell, 1997), klason lignin (TAPPI T 222), ash (TAPPI T 211), ethanol solubility (TAPPI T 204), cold and hot water solubility (TAPPI T 207), and $1 \% \mathrm{NaOH}$ solubility (TAPPI T 212) were carried out according to relevant standard methods. Three repetitions were made for each experiment.

\subsection{Fiber analysis}

\subsection{Analiza vlakana}

Bracken stalk samples were macerated according to chlorite method (Spearin and Isenberg, 1947). After maceration, the samples were agitated to obtain individual fibers (Berlyn and Miksche, 1976). The fiber length, fiber width, lumen width, and cell wall thickness of 50 randomly-selected fibers were measured. The slenderness ratio (fiber length/fiber width), flexibility ratio [(lumen width/fiber width $) \times 100$ ], and Runkel ratio $[(2 \times$ cell wall thickness $) /$ lumen width] were calculated using the measured fiber dimensions.

\subsection{Pulping and handsheet properties \\ 2.4. Proizvodnja celuloze i svojstva papira}

The kraft pulps made from bracken stalks were prepared under the following conditions: active alkali as $\mathrm{Na}_{2} \mathrm{O} 25 \%$, sulfidity $30 \%$, liquor/wood ratio 5:1, pulping temperature $170{ }^{\circ} \mathrm{C}$, heating time to $170{ }^{\circ} \mathrm{C} 90$ min., and time at temperature $75 \mathrm{~min}$. The same pulping conditions were applied to $0.5 \%, 1 \%, 1.5 \%$, and $2 \% \mathrm{NaBH}_{4}$ and $\mathrm{KBH}_{4}$ added samples. In pulping, laboratory-type 15 -L electrically-heated rotary digester was used. In order to remove the black liquor, the pulps were washed and disintegrated. The rejects were retained by a Somerville-type pulp screen with a 0.15 mm slotted plate (TAPPI T 275). All pulps were beaten according to TAPPI T 200 to $25{ }^{\circ} \mathrm{SR}$ in a Valley Beater for comparison in the same conditions. The kappa number, screened yield and freeness levels of all pulps were determined according to TAPPI T 236, TAPPI T 210, and ISO 5267-1, respectively. Ten handsheets (75 $\mathrm{g} / \mathrm{m}^{2}$ ) were formed with a Rapid-Kothen Sheet Former (ISO 5269-2). The handsheets were conditioned according to TAPPI T 402. The tensile index, tensile energy absorption (TEA), and stretch (ISO 1924), burst index (TAPPI T 403), tear index (TAPPI T 414), and brightness (TAPPI $\mathrm{T}$ 525) of the handsheets were measured using the relevant standard methods. 


\subsection{Statistical analysis}

\subsection{Statistička analiza}

All data was performed using SPSS software. The data belonging to the kraft and kraft- $\mathrm{NaBH}_{4}$, and kraft- $\mathrm{KBH}_{4}$ pulp properties of the bracken stalks were analyzed with analysis of variance (ANOVA). The effects of boron compound addition on paper properties were evaluated statistically. All pair wise multiple comparison procedures were performed using Duncan's test $(p<0.05)$. The same letter in figures denotes that there were no statistically significant differences between the groups.

\section{RESULTS AND DISCUSSION} 3. REZULTATI I RASPRAVA

\subsection{Chemical composition}

3.1. Kemijski sastav

The chemical composition of a lignocellulosic raw material has been an important factor in evaluating its suitability for pulp production. The high holocellulose content and low lignin content have been desired for pulping to obtain higher pulp yield and lower kappa number. Also, pulp yield substantially depends on $\alpha$-cellulose content of raw material used in pulp production. Table 1 shows the chemical composition of bracken stalks and its comparison with other lignocellulosic materials. As can be seen in Table 1, holocellu- lose content of bracken stalks was found to be $73.34 \%$, which is comparable with other annual plants, lower than eucalyptus $(80.47 \%)$ and aspen $(82.68 \%)$, and higher than maritime pine $(70.21 \%)$.

The $\alpha$-cellulose content of raw material is an indicator of pulp yield. Fibers having higher $\alpha$-cellulose content have been preferred for chemical pulp production. The $\alpha$-cellulose content of bracken stalks (32.55 $\%$ ) was lower than that of other annual plants. Also, it was lower than that of eucalyptus $(52.79 \%)$, aspen $(49.03 \%)$, and maritime pine $(47.11 \%)$, higher than that of cotton stalks $(29.74 \%)$.

The klason lignin content of bracken stalks $(30.79 \%)$ was higher than that of most annual plants. Also, it was higher than that of eucalyptus (19.96\%), aspen $(16.69 \%)$, and maritime pine $(28.23 \%)$. The high lignin content in raw material causes longer pulping time and increases the requirement of chemicals for delignification. Therefore, low lignin content in lignocellulosic raw material has been seen as an advantage for chemical pulping.

The solubility in water provides no useful information concerning the pulping value of the raw material, but it indicates the nature of certain constituents. In the cold water procedure, inorganic compounds, tannins, gums, sugars, and coloring matters are removed from raw material. The hot water procedure additionally removes starch. Treatment of raw material with 1

Table 1 Comparison of chemical composition of bracken stalks with other lignocellulosic species

Tablica 1. Usporedba kemijskog sastava stabljika paprati s drugim lignoceluloznim sirovinama

\begin{tabular}{|c|c|c|c|c|c|c|c|c|c|}
\hline $\begin{array}{l}\text { Raw materials } \\
\text { Sirovina }\end{array}$ & $\begin{array}{l}\mathbf{H} \\
\%\end{array}$ & $\begin{array}{c}\mathrm{AC} \\
\%\end{array}$ & $\begin{array}{l}\text { KL } \\
\%\end{array}$ & $\begin{array}{l}\text { ES } \\
\%\end{array}$ & $\begin{array}{c}\text { HWS } \\
\%\end{array}$ & $\begin{array}{c}\text { CWS } \\
\%\end{array}$ & $\begin{array}{c}\mathrm{NaOH} \\
\%\end{array}$ & $\begin{array}{c}\text { Ash } \\
\%\end{array}$ & Literature \\
\hline Bracken stalks / stabljike paprati & 73.34 & 32.55 & 30.79 & 7.19 & 15.45 & 14.60 & 28.08 & 7.45 & This study \\
\hline Cotton stalks / stabljike pamuka & 62.79 & 29.74 & 23.79 & - & 17.91 & 15.05 & 48.88 & 4.99 & Ateş et al., (2015) \\
\hline Corn stalks / stabljike kukuruza & 64.80 & 35.60 & 17.40 & $9.50 *$ & 14.8 & - & 47.10 & 7.5 & Usta et al., (1990) \\
\hline Sorghum stalks / stabljike sirka & 71.0 & 40.3 & 13.0 & 15.3 & 19.7 & 15.1 & 47.1 & - & $\begin{array}{l}\text { Gençer and Şahin, } \\
(2015)\end{array}$ \\
\hline Sunflower stalks / stabljike suncokreta & 66.9 & 37.6 & 10.8 & $4.07 *$ & 21.1 & - & 50.4 & - & López et al., (2005) \\
\hline Tobacco stalks / stabljike duhana & 67.79 & 39.20 & 18.90 & $7.10 *$ & 20.02 & 16.85 & 42.00 & 6.86 & Shakhes et al., (2011) \\
\hline Canola stalks / stabljike uljane repice & 72.1 & 39.9 & 20.6 & 1.6 & 8.6 & 7.5 & 29.1 & 5.8 & Tofanica et al., (2011) \\
\hline Wheat straw / slama od pšenice & 69.84 & 42.07 & 22.33 & $9.33^{*}$ & 14.71 & 11.33 & 53.67 & 11.63 & Ateş et al., (2015) \\
\hline Barley straw / slama od ječma & 66.01 & 38.70 & 19.47 & - & 16.25 & 11.01 & 56.25 & 10.97 & Ateş et al., (2015) \\
\hline Rice straw / slama od riže & 70.85 & 35.62 & 17.2 & $3.52 *$ & 16.24 & 10.65 & 49.15 & 16.6 & Tutus et al., (2004) \\
\hline Rye straw / slama od raži & 74.1 & 44.4 & 15.4 & $9.2 *$ & 13.0 & 10.2 & 39.2 & 3.2 & Usta and Eroglu, (1988) \\
\hline Kenaf / kenaf & 71.8 & 46.75 & 17.30 & $4.28 *$ & 6.42 & 4.56 & 28.50 & 1.56 & Dutt et al., (2009) \\
\hline Hemp konoplja & 86.93 & 63.77 & 6.59 & $4.23 *$ & 9.06 & 7.75 & 29.55 & - & $\begin{array}{l}\text { Gümüşkaya and Usta, } \\
(2006)\end{array}$ \\
\hline $\begin{array}{l}\text { Sugarcane bagasse (depithed) } \\
\text { ostatci od prerade šećerne trske }\end{array}$ & 71.03 & 42.34 & 21.7 & $1.85^{*}$ & 7.42 & 3.02 & 32.29 & 2.10 & Agnihotri et al., (2010) \\
\hline Bamboo / bambus & 68.33 & 47.67 & 26.00 & $3.68 *$ & 5.53 & 4.61 & 19.82 & 1.98 & Moradbak et al., (2016) \\
\hline Paulownia / drvo paul & 75.74 & 43.61 & 20.5 & 3.76 & 10.05 & 8.50 & 24.50 & 0.21 & Ates et al., (2008) \\
\hline Eucalyptus globulus & 80.47 & 52.79 & 19.96 & $1.15^{*}$ & 2.84 & - & 12.42 & 0.57 & Jiménez et al., (2008) \\
\hline European aspen / drvo jasike & 82.68 & 49.03 & 16.69 & 3.22 & 3.04 & 3.22 & 15.34 & 0.31 & $\begin{array}{l}\text { Gulsoy and Tufek, } \\
\text { (2013) }\end{array}$ \\
\hline Maritime pine / drvo primorskog & 70.21 & 47.11 & 28.23 & 4.15 & 3.67 & 1.64 & 9.71 & 0.27 & $\begin{array}{l}\text { Gulsoy and Tufek, } \\
\text { (2013) }\end{array}$ \\
\hline
\end{tabular}

H: Holocellulose / holoceluloza, AC: $\alpha$-cellulose / $\alpha$-celuloza, KL: Klason lignin / klason lignin, ES: Ethanol solubility / topljivost $u$ etanolu, HWS: Hot water solubility / topljivost $u$ vrućoj vodi, CWS: Cold water solubility / topljivost u hladnoj vodi, $\mathrm{NaOH}: 1 \% \mathrm{NaOH}$ solubility / topljivost u $1 \%$-tnom $\mathrm{NaOH}$, *: Alcohol benzene solubility / topljivost u alkohol benzenu, **: Acetone solubility / topljivost $u$ acetonu, ${ }^{* * *}$ : Ethanol-toluene solubility / topljivost $u$ etanol-toluenu 
$\% \mathrm{NaOH}$ causes the extraction of low-molecularweight carbohydrates consisting mainly of hemicelluloses and degraded cellulose. Also, this treatment is an indication of decay degree in the raw material. The high content of $1 \% \mathrm{NaOH}$ soluble of the rapeseed stalks and depithed stalks may probably affect the pulp yields and also the chemical consumption (Tofanica et al., 2011). Ethanol, hot water, cold water, and $1 \%$ $\mathrm{NaOH}$ solubility of bracken stalks were found to be $7.19 \%, 15.45 \%, 14.60 \%$, and 28.08, respectively. These values were similar to those of other nonwood lignocellulosic raw materials, higher than those of hardwood and softwood species. According to chemical composition results, bracken stalks can be evaluated as an alternative raw material for pulp production, although they have low $\alpha$-cellulose content and high lignin content.

Like most nonwood fibers, the ash content of bracken stalks $(7.45 \%)$ was higher than that of wood species. Also, it was similar to that of corn stalks (7.5 $\%)$, lower than that of wheat straw $(11.63 \%)$, barley straw $(10.97 \%)$, and rice straw $(16.6 \%)$. High quantity of ash content in the lignocellulosic raw material can cause problems in pulping and papermaking processes. It can have a negative effect on chemical consumption during pulping, refining, and recovery of the cooking liquor.

\subsection{Fiber morphology}

\subsection{Morfologija vlakana}

One of the important factors in evaluating the suitability of pulp production of a raw material is its fiber morphological properties. The fiber properties directly affect the runnability on paper machine, strength and optical properties of sheet, response to refining, and fiber-water interactions, such as swelling and water retention of fibers. Long fibers are predisposed to form a porous and less uniform paper structure, coarse paper surface. Also, sheets of long fibers have higher strength properties than sheets of short fibers. On the other hand, fiber flexibility depends on lumen width and cell wall thickness of fibers. Thick-walled fibers have a negative effect on the folding endurance, burst and tensile index of paper, and a positive effect on tear index. Also, the paper obtained from thick walled fibers will be bulky, with a coarse surface, and will contain a large amount of void volume. However, thinwalled fibers provide uniform and denser paper structure.

Table 2 shows fiber properties of bracken stalks and comparison of these fiber properties with some lignocellulosic materials. As seen in Table 2, average fiber length of bracken stalks was $1.25 \mathrm{~mm}$. Fiber length of bracken is similar than that of tobacco stalks (1.23 $\mathrm{mm})$, kenaf (1.29 mm). Fiber length of bracken stalks was shorter than that of maritime pine $(2.4 \mathrm{~mm})$, bamboo $(1.98 \mathrm{~mm})$, sorghum stalks $(1.77 \mathrm{~mm})$, and sugarcane bagasse $(1.59 \mathrm{~mm})$, and longer than that of European aspen $(1.1 \mathrm{~mm})$, river red gum $(0.80 \mathrm{~mm})$, cotton stalks $(0.83 \mathrm{~mm})$, sunflower stalks $(0.76 \mathrm{~mm})$, rice straw $(0.99 \mathrm{~mm})$.
The fiber width of bracken stalks $(24 \mu \mathrm{m})$ was close to that of corn stalks $(24.30 \mu \mathrm{m})$, tobacco stalks $(24.31 \mu \mathrm{m})$, and European aspen $(23.9 \mu \mathrm{m})$. It was wider than that of cotton stalks $(19.60 \mu \mathrm{m})$, sorghum stalks $(19.53 \mu \mathrm{m})$, and rice straw $(11.99 \mu \mathrm{m})$, and narrower than that of maritime pine $(43.7 \mu \mathrm{m})$, paulownia $(36.3 \mu \mathrm{m})$, and hemp $(29.5 \mu \mathrm{m})$.

The lumen width of bracken stalks $(10.30 \mu \mathrm{m})$ was similar to that of other nonwood fibers, such as corn stalks $(10.70 \mu \mathrm{m})$ and wheat straw $(10.54 \mu \mathrm{m})$. It was wider than that of sorghum stalks $(6.60 \mu \mathrm{m})$, rice straw $(5.26 \mu \mathrm{m})$, and river red gum $(7.2 \mu \mathrm{m})$, and narrower than that of sunflower stalks $(16.00 \mu \mathrm{m})$, tobacco stalks $(15.38 \mu \mathrm{m})$, maritime pine $(29.5 \mu \mathrm{m})$, paulownia $(19.2 \mu \mathrm{m})$, and hemp $(15.2 \mu \mathrm{m})$.

The cell wall thickness of bracken stalks $(6.85$ $\mu \mathrm{m})$ was close to that of corn stalks $(6.80 \mu \mathrm{m})$, sorghum stalks $(6.46 \mu \mathrm{m})$ and European aspen $(6.30 \mu \mathrm{m})$. It had thicker cell wall than cotton stalks $(3.40 \mu \mathrm{m})$, canola stalks $(5.26 \mu \mathrm{m})$, wheat straw $(4.39 \mu \mathrm{m})$, and thinner cell wall than hemp $(7.1 \mu \mathrm{m})$, paulownia $(8.6$ $\mu \mathrm{m})$, and maritime pine $(7.1 \mu \mathrm{m})$.

Slenderness ratio, felting ratio, and Runkel ratio, derived from fiber dimensions, have been used to determine the suitability of lignocellulosic raw materials for pulp production. High length to width ratio (slenderness ratio) of fibers results in well bonded paper. High slenderness ratio (>33) means that lignocellulosic raw material is suitable for pulp and paper production (Xu et al., 2006). Slenderness ratio of bracken stalks (52.8) was comparable with that of other raw materials as shown in Table 2. It was very close to slenderness ratio of river red gum (53.33), lower than that of sorghum stalks (90.37) and rice straw (86.04), and higher than that of sunflower stalks (30.06) and paulownia (22.58).

Flexibility ratio (lumen to fiber width) of fibers is classified as highly elastic fibers $(>75)$, elastic fibers (50-70), rigid fibers (30-50), and very rigid fibers $(<30)$. Flexibility ratio of bracken stalks (42.92) was comparable with that of other raw materials, as shown in Table 2. It was very close to flexibility ratio of corn stalks (44.03), lower than that of sunflower stalks (64.96) and maritime pine (67.5), and higher than that of sorghum stalks (33.79). According to flexibility ratio, the fibers of bracken stalks can be classified into rigid fibers group.

The flexible fibers, having low Runkel ratio (wall to lumen ratio, <1) are easily collapsible, and give large surface area for interfiber bonding. The rigid fibers, having high Runkel ratio $(>1)$, have low bonded area. These fibers are least suitable for paper production due to their stiff fibers. Runkel ratio of bracken stalks (1.33) was comparable with that of other raw materials, as shown in Table 2. It was very close to Runkel ratio of rice straw (1.31), lower that that of switchgrass (1.5), and higher than that of maritime pine (0.5) and European aspen (1.1). Bracken stalks fibers are classified into rigid fibers category in terms of their Runkel ratio value. According to fiber morphology results, bracken stalks can be used for pulp production as 
.... Koray Gülsoy, Şimşir: Chemical Composition, Fiber Morphology, and Kraft Pulping...

Table 2 Comparison of fiber properties of bracken stalks with other lignocellulosic biomasses

Tablica 2. Usporedba svojstava vlakana stabljike paprati s drugim vrstama lignocelulozne biomase

\begin{tabular}{|c|c|c|c|c|c|c|c|c|}
\hline $\begin{array}{l}\text { Raw materials } \\
\text { Sirovina }\end{array}$ & $\begin{array}{c}\text { FL } \\
(L) \\
\mathrm{mm}\end{array}$ & $\begin{array}{l}\text { FW } \\
(D) \\
\mu \mathrm{m}\end{array}$ & $\begin{array}{l}\mathbf{L W} \\
(d) \\
\mu \mathrm{m}\end{array}$ & $\begin{array}{c}\text { CWT } \\
(w) \\
\mu \mathrm{m}\end{array}$ & $\begin{array}{l}\text { SR } \\
L / D\end{array}$ & $\begin{array}{c}\text { FR } \\
(d / D) \times 100\end{array}$ & $\begin{array}{l}\mathrm{RR} \\
2 w / d\end{array}$ & Literature \\
\hline Bracken stalks / stabljike paprati & 1.25 & 24.00 & 10.30 & 6.85 & 52.08 & 42.92 & 1.33 & This study \\
\hline Corn stalks / stabljike kukuruza & 1.32 & 24.30 & 10.7 & 6.8 & 54.32 & 44.03 & 1.27 & Usta et al., (1990) \\
\hline Cotton stalks / stabljike pamuka & 0.83 & 19.60 & 12.80 & 3.40 & 42.35 & 65.31 & 0.53 & Ververis et al., (2004) \\
\hline $\begin{array}{l}\text { Canola stalks } \\
\text { stabljike uljane repice }\end{array}$ & 1.17 & 23.02 & 12.5 & 5.26 & 50.83 & 54.30 & 0.84 & Enayati et al., (2009) \\
\hline $\begin{array}{l}\text { Sunflower stalks } \\
\text { stabljike suncokreta }\end{array}$ & 0.76 & 25.20 & 16.00 & 4.42 & 30.06 & 64.96 & 0.54 & $\begin{array}{l}\text { Omotoso and Owolabi, } \\
\text { (2015) }\end{array}$ \\
\hline Sorghum stalks / stabljike sirka & 1.77 & 19.53 & 6.60 & 6.46 & 90.37 & 33.79 & 1.90 & Albert et al., (2011) \\
\hline Tobacco stalks / stabljike duhana & 1.23 & 24.31 & 15.38 & 4.47 & 50.59 & 63.26 & 1.16 & Shakhes et al., (2011) \\
\hline Wheat straw / slama od pšenice & 1.14 & 19.32 & 10.54 & 4.39 & 59 & 54.55 & 0.83 & $\begin{array}{l}\text { Kasmani and Samari- } \\
\text { ha, (2011) }\end{array}$ \\
\hline Rice straw / slama od riže & 0.99 & 11.99 & 5.26 & 3.36 & 86.04 & 45.87 & 1.31 & Kiaei, 2014 \\
\hline $\begin{array}{l}\text { Sugarcane bagasse } \\
\text { ostatci od prerade šećerne trske }\end{array}$ & 1.59 & 20.96 & 9.72 & 5.64 & 75.86 & 46.37 & 1.16 & Hemmasi et al., (2011) \\
\hline Kenaf / kenaf & 1.29 & 22.1 & 12.7 & 4.3 & 58.3 & 57.5 & 0.67 & Ververis et al., (2004) \\
\hline Switchgrass / trave & 1.15 & 13.1 & 5.8 & 4.6 & 87.7 & 44.2 & 1.5 & Ververis et al., (2004) \\
\hline Miscanthus / kineski šaš & 0.97 & 14.2 & 5.9 & 4.1 & 68.3 & 41.5 & 1.3 & Ververis et al., (2004) \\
\hline Hemp / konoplja & 1.8 & 29.5 & 15.2 & 7.1 & - & 51.5 & 0.93 & Dutt et al., (2008) \\
\hline $\begin{array}{l}\text { Musa paradisiaca (banana) } \\
\text { banana }\end{array}$ & 1.55 & 22 & 14.2 & 5.5 & 70.5 & - & 0.77 & Goswami et al., (2008) \\
\hline Bamboo / bambus & 1.98 & 17.27 & 8.66 & 3.74 & 114.64 & 50.14 & 0.86 & Moradbak et al., (2016) \\
\hline Paulownia / drvo paulovnije & 0.82 & 36.3 & 19.2 & 8.6 & 22.58 & 53.08 & 0.89 & Ates et al., (2008) \\
\hline River red gum / drvo eukaliptusa & 0.80 & 15.0 & 7.2 & 4.0 & 53.33 & 48.0 & 1.11 & Dutt and Tyagi, (2011) \\
\hline European aspen / drvo jasike & 1.1 & 23.9 & 11.4 & 6.3 & 46.0 & 47.7 & 1.1 & $\begin{array}{l}\text { Gulsoy and Tufek, } \\
\text { (2013) }\end{array}$ \\
\hline $\begin{array}{l}\text { Maritime pine } \\
\text { drvo primorskog bora }\end{array}$ & 2.4 & 43.7 & 29.5 & 7.1 & 54.9 & 67.5 & 0.5 & $\begin{array}{l}\text { Gulsoy and Tufek, } \\
\text { (2013) }\end{array}$ \\
\hline
\end{tabular}

FL: Fiber length / duljina vlakna, FW: Fiber width / širina vlakna, LW: Lumen width / širina lumena, CWT: Cell wall thickness / debljina stanične stijenke, SR: Slenderness ratio / omjer vitkosti, FR: Flexibility ratio / omjer fleksibilnosti, RR: Runkel ratio / Runkelov omjer

an alternative raw material, although they have relatively short and rigid fibers.

\subsection{Pulp and paper properties}

3.3. Svojstva celuloze i papira

Some properties of kraft, kraft-NaBH${ }_{4}$, and kraft$\mathrm{KBH}_{4}$ pulps are given in Table 3. The screened and total yields of bracken stalks control kraft pulp were relatively lower compared to conventional kraft pulp yield. This result can be explained by low $\alpha$-cellulose content of bracken stalks (Table 2). On the other hand, pulp yields increased with the addition of $\mathrm{NaBH}_{4}$ and $\mathrm{KBH}_{4}$. The highest total pulp yield was found to be $36.9 \%$ in $2 \% \mathrm{KBH}_{4}$ added pulp. Similar total yield increases with the addition of $\mathrm{NaBH}_{4}$ (Akgül et al., 2007; Istek and Gonteki, 2009; Tutus et al., 2010a,b; Gulsoy and Eroglu, 2011; Gümüşkaya et al., 2011; Erişir et al., 2015; Saraçbaş1 et al., 2016) and $\mathrm{KBH}_{4}$ (Gülsoy et al., 2016) have been reported by several authors. This result could be attributed to carbohydrate retention increases with the addition of boron compounds.

Residual lignin content of pulp was calculated by multiplying the kappa number by 0.13 . Bleachable-grade chemical pulp (kraft or sulfite) usually contains about $1.5-4.5 \%$ residual lignin (Gellerstedt, 2010). The residual lignin content of bracken stalks control pulp $(45.1 \times 0.13=5.86 \%)$ was slightly high- er than that of bleachable-grade. This finding could be explained by high lignin content of bracken stalks (Table 2). The kappa numbers of pulps decreased with increasing boron compound addition ratios. This findng can be attributed to the acceleration of delignification rate with $\mathrm{NaBH}_{4}$ and $\mathrm{KBH}_{4}$ additions. The lowest kappa number was found to be 30.9 in $2 \%$ $\mathrm{KBH}_{4}$ added pulp. Several authors reported a positive effect of $\mathrm{NaBH}_{4}$ on kappa number (Tutus et al., 2010b; Gulsoy and Eroglu, 2011; Gümüşkaya et al., 2011; Erişir et al., 2015; Saraçbaş1 et al., 2016). On the other hand, Gülsoy et al., (2016) noted that $\mathrm{KBH}_{4}$ had a negative effect on kappa number of maritime pine kraft pulp. $\mathrm{NaBH}_{4}$, and $\mathrm{KBH}_{4}$ additions to cooking liquor resulted in pulp viscosity increases. This result can be attributed to the prevention of degradation reactions by $\mathrm{NaBH}_{4}$ and $\mathrm{KBH}_{4}$ during cooking. The effect of $\mathrm{KBH}_{4}$ on pulp properties was more prominent than the effect of $\mathrm{NaBH}_{4}$. The highest pulp viscosity was found to be $841 \mathrm{~cm}^{3} / \mathrm{g}$ in $2 \% \mathrm{KBH}_{4}$ added pulp. Several authors reported a positive effect of $\mathrm{NaBH}_{4}$ on pulp viscosity (Akgül and Temiz, 2006; Akgül et al., 2007; Istek and Özkan, 2008; Tutus et al., 2010b). On the contrary, pulp viscosity decreased with $\mathrm{NaBH}_{4}$ addition (Çöpür and Tozluoğlu, 2008; Gulsoy and Eroglu, 2011; Gümüşkaya et al., 2011; Saraçbaş1 et al., 2016). 
Table 3 Some pulp properties of kraft, kraft- $\mathrm{NaBH}_{4}$, kraft- $\mathrm{KBH}_{4}$ pulps

Tablica 3. Neka svojstva kraft, kraft-NaBH4 i kraft-KBH4 celuloze

\begin{tabular}{|l|c|c|c|c|c|}
\hline $\begin{array}{l}\text { Cooking } \\
\text { Kuhanje }\end{array}$ & $\begin{array}{c}\text { Screened Yield } \\
\text { Prinos prosijavanja } \\
\%\end{array}$ & $\begin{array}{c}\text { Reject } \\
\text { Škart prosijavanja } \\
\%\end{array}$ & $\begin{array}{c}\text { Total yield } \\
\text { Ukupni prinos } \\
\%\end{array}$ & $\begin{array}{c}\text { Kappa number } \\
\text { Kapa broj }\end{array}$ & $\begin{array}{c}\text { Viscosity } \\
\text { Viskoznost } \\
\text { cm }^{3} / \mathrm{g}\end{array}$ \\
\hline Control & 34.43 & 0.15 & 34.58 & 45.10 & 741 \\
\hline $0.5 \% \mathrm{NaBH}_{4}$ & 34.67 & 0.17 & 34.84 & 43.70 & 788 \\
\hline $1 \% \mathrm{NaBH}_{4}$ & 36.54 & 0.17 & 36.71 & 42.90 & 779 \\
\hline $1.5 \% \mathrm{NaBH}_{4}$ & 36.45 & 0.19 & 36.64 & 40.90 & 795 \\
\hline $2 \% \mathrm{NaBH}_{4}$ & 36.20 & 0.38 & 36.58 & 39.80 & 812 \\
\hline Control & 34.43 & 0.15 & 34.58 & 45.10 & 741 \\
\hline $0.5 \% \mathrm{KBH}_{4}$ & 34.84 & 0.24 & 35.08 & 38.00 & 808 \\
\hline $1 \% \mathrm{KBH}_{4}$ & 34.94 & 0.06 & 35.00 & 35.20 & 772 \\
\hline $1.5 \% \mathrm{KBH}_{4}$ & 36.47 & 0.30 & 36.77 & 36.50 & 829 \\
\hline $2 \% \mathrm{KBH}_{4}$ & 36.75 & 0.15 & 36.90 & 30.60 & 841 \\
\hline
\end{tabular}

The comparison of kraft pulp properties of bracken stalks with other lignocellulosic raw materials is presented in Table 4. Bracken stalks had lower screened yield and brightness, and higher kappa number than other nonwood species. This result can be attributed to low $\alpha$-cellulose and high lignin content of bracken stalks.

At the similar pulp freeness levels, handsheet strength properties of bracken stalks kraft pulp were determined to be comparable with hardwood and nonwood papermaking raw materials. Tensile index (68.69 $\mathrm{N} \cdot \mathrm{m} / \mathrm{g}$ ) of handsheets of bracken stalks kraft pulp at 25 ${ }^{\circ} \mathrm{SR}$ freeness level was higher than that of European aspen kraft pulp at $30^{\circ} \mathrm{SR}$ freeness level $(61.13 \mathrm{~N} \cdot \mathrm{m} / \mathrm{g})$, kenaf kraft pulp at $30{ }^{\circ} \mathrm{SR}$ freeness $(50.23 \mathrm{~N} \cdot \mathrm{m} / \mathrm{g})$, sweet bamboo kraft pulp at $25{ }^{\circ} \mathrm{SR}$ freeness (63.01 $\mathrm{N} \cdot \mathrm{m} / \mathrm{g}$ ), and lower than switchgrass kraft pulp at 30 ${ }^{o} \mathrm{SR}$ freeness level $(74.48 \mathrm{~N} \cdot \mathrm{m} / \mathrm{g})$.

At the similar pulp freeness levels, tear index of handsheets of bracken stalks kraft pulp $\left(7.12 \mathrm{mN} \cdot \mathrm{m}^{2} / \mathrm{g}\right)$ was higher than kraft pulps of thistle stalks (6.7 $\left.\mathrm{mN} \cdot \mathrm{m}^{2} / \mathrm{g}\right)$, switchgrass $\left(6.67 \mathrm{mN} \cdot \mathrm{m}^{2} / \mathrm{g}\right)$, European aspen $\left(6.38 \mathrm{mN} \cdot \mathrm{m}^{2} / \mathrm{g}\right)$, and river red gum $\left(6.6 \mathrm{mN} \cdot \mathrm{m}^{2} / \mathrm{g}\right)$.
Also, it was lower than kenaf $\left(10.30 \mathrm{mN} \cdot \mathrm{m}^{2} / \mathrm{g}\right)$. Burst index of handsheets of bracken stalks kraft pulp (2.98 $\left.\mathrm{kPa} \cdot \mathrm{m}^{2} / \mathrm{g}\right)$ were similar to kenaf kraft pulp (2.94 $\mathrm{kPa} \cdot \mathrm{m}^{2} / \mathrm{g}$ ). It was lower than kraft pulps of nonwood (thistle stalks and switchgrass) and hardwood (European aspen and river red gum) species (Table 4).

The effect of $\mathrm{NaBH}_{4}$ and $\mathrm{KBH}_{4}$ additions on tensile index of handsheets is given in Figure 1. Tensile index increased with $\mathrm{NaBH}_{4}$ and $\mathrm{KBH}_{4}$ additions except for $1.5 \% \mathrm{NaBH}_{4}$ and $1 \% \mathrm{KBH}_{4}$ added pulps $(p<0.05)$. The highest tensile index was determined in $0.5 \%$ $\mathrm{NaBH}_{4}$ added pulp with $74.01 \mathrm{~N} \cdot \mathrm{m} / \mathrm{g}$. Increased tensile index can be attributed to increasing hemicellulose retention in boron compounds added pulps. Higher hemicellulose content results in an increase of pulp strength. Gulsoy and Eroglu (2011) noted that tensile index increased in European black pine kraft pulp, and Gümüşkaya et al., (2011) noted that it increased in stone pine AS-AQ pulp with $\mathrm{NaBH}_{4}$ addition. On the contrary, some authors noted that $\mathrm{NaBH}_{4}$ had a negative effect on tensile index of handsheets (Akgül et al., 2007; Çöpür ve Tozluoğlu, 2008; Istek and Özkan, 2008).

Table 4 Comparison of kraft pulp properties of bracken stalks with other lignocellulosic raw materials Tablica 4. Usporedba svojstava kraft celuloze od stabljika paprati s drugim lignoceluloznim sirovinama

\begin{tabular}{|l|c|c|c|c|c|c|c|}
\hline & $\begin{array}{c}\text { Bracken } \\
\text { stalks } \\
\text { Stabljike } \\
\text { paprati } \\
(1)\end{array}$ & $\begin{array}{c}\text { Kenaf } \\
\text { Kenaf }\end{array}$ & $\begin{array}{c}\text { Thistle } \\
\text { stalks } \\
\text { Stabljike } \\
\text { čička } \\
(2)\end{array}$ & $\begin{array}{c}\text { Switchgrass } \\
\text { Trave }\end{array}$ & $\begin{array}{c}\text { Sweet } \\
\text { bamboo } \\
\text { Bambus }\end{array}$ & $\begin{array}{c}\text { European } \\
\text { aspen } \\
\text { Jasika } \\
(4)\end{array}$ & $\begin{array}{c}\text { River red } \\
\text { gum } \\
\text { Eukaliptus } \\
(7)\end{array}$ \\
\hline Cooking type / Tip kuhanja & Kraft & Kraft & Kraft & Kraft & Kraft & Kraft & Kraft \\
\hline $\begin{array}{l}\text { Screened yield, \% } \\
\text { Prinos prosijavanja, \% }\end{array}$ & 34.43 & 51.0 & 40.00 & 42.74 & 46.32 & 53.8 & 43.9 \\
\hline Kappa number / Kapa broj & 45.1 & 30.2 & 15.0 & 14.01 & 12.54 & 12.8 & 24.4 \\
\hline Brightness, \% / Sjajnost, \% & 16.29 & - & - & 29.30 & 19.67 & 27.78 & 25.9 \\
\hline Freeness level $\left({ }^{\circ} \mathrm{SR} /\right.$ / Razina slobode & 25 & 30 & 24 & 30 & 25 & 35 & 25 \\
\hline $\begin{array}{l}\text { Tensile index, N·m/g } \\
\text { Vlačni indeks, } \mathrm{N} \cdot \mathrm{m} / \mathrm{g}\end{array}$ & 68.69 & 50.23 & 63.6 & 74.88 & 63.01 & 61.13 & 60.2 \\
\hline $\begin{array}{l}\text { Tear index, } \mathrm{mN} \cdot \mathrm{m}^{2} / \mathrm{g} \\
\text { Indeks cijepanja, } \mathrm{mN} \cdot \mathrm{m}^{2} / \mathrm{g}\end{array}$ & 7.12 & 10.30 & 6.7 & 6.67 & - & 6.38 & 6.6 \\
\hline $\begin{array}{l}\text { Burst index, } \mathrm{kPa} \cdot \mathrm{m}^{2} / \mathrm{g} \\
\text { Indeks pucanja, } \mathrm{kPa} \cdot \mathrm{m}^{2} / \mathrm{g}\end{array}$ & 2.98 & 2.94 & 3.4 & 4.16 & 3.19 & 4.71 & 3.2 \\
\hline
\end{tabular}

1: This study, 2: Dutt et al., (2009), 3: Gominho et al., (2001), 4: Madakadze et al., (1999), 5: Kamthai and Puthson, (2005), 6: Gulsoy and Tufek, (2013), 7: Khristova et al., (2006). 




Figure 1 Effect of $\mathrm{NaBH}_{4}$ and $\mathrm{KBH}_{4}$ additions on tensile index of handsheets Slika 1. Utjecaj dodavanja $\mathrm{NaBH}_{4}$ i $\mathrm{KBH}_{4}$ na vlačni indeks uzoraka papira



Figure 2 Effect of $\mathrm{NaBH}_{4}$ and $\mathrm{KBH}_{4}$ additions on stretch of handsheets Slika 2. Utjecaj dodavanja $\mathrm{NaBH}_{4}$ i $\mathrm{KBH}_{4}$ na rastezanje uzoraka papira

The effect of $\mathrm{NaBH}_{4}$ and $\mathrm{KBH}_{4}$ additions on stretch values of handsheets is given in Figure 2. The stretch values of handsheets increased with $\mathrm{NaBH}_{4}$ and $\mathrm{KBH}_{4}$ additions except for $2 \% \mathrm{KBH}_{4}$ added pulp $(p<0.05)$. The highest stretch value was determined in $0.5 \% \mathrm{NaBH}_{4}$ added pulp with $2.00 \%$. Istek and Gonteki (2009) noted that $\mathrm{NaBH}_{4}$ addition to maritime pine kraft cooking caused losses in stretch values of handsheets.

The effect of $\mathrm{NaBH}_{4}$ and $\mathrm{KBH}_{4}$ additions on TEA values of handsheets is given in Figure 3. The TEA val-

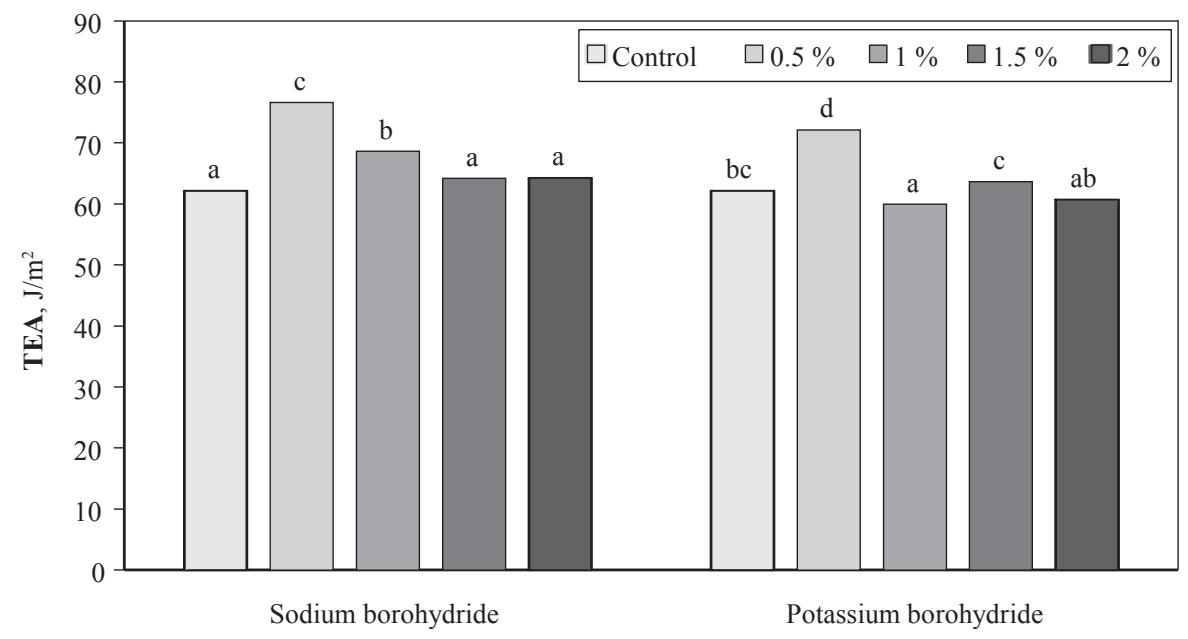

Figure 3 Effect of $\mathrm{NaBH}_{4}$ and $\mathrm{KBH}_{4}$ additions on TEA of handsheets

Slika 3. Utjecaj dodavanja $\mathrm{NaBH}_{4}$ i $\mathrm{KBH}_{4}$ na TEA uzoraka papira 
ues of handsheets increased with $\mathrm{NaBH}_{4}$ and $\mathrm{KBH}_{4}$ additions except for $1 \%$ and $2 \% \mathrm{KBH}_{4}$ added pulps $(p<0.05)$. The highest TEA value was determined in $0.5 \% \mathrm{NaBH}_{4}$ added pulp with $76.66 \mathrm{~J} / \mathrm{m}^{2}$. Similar TEA losses were reported by Istek and Gonteki (2009).

The effect of $\mathrm{NaBH}_{4}$ and $\mathrm{KBH}_{4}$ additions on tear index of handsheets is given in Figure 4. Tear index decreased with $\mathrm{NaBH}_{4}$ and $\mathrm{KBH}_{4}$ additions $(p<0.05)$. Tear index losses can be attributed to higher pulp yield of $\mathrm{NaBH}_{4}$ and $\mathrm{KBH}_{4}$ added pulps. Increasing in pulp yield causes the decrease of the fiber per unit weight of oven-dried pulp. The lowest tear index was determined in $2 \% \mathrm{NaBH}_{4}$ added pulp with $5.82 \mathrm{mN} \cdot \mathrm{m}^{2} / \mathrm{g}$. Similar tear index losses were reported in earlier studies (Akgül et al., 2007; Çöpür and Tozluoğlu, 2008; Istek and Gonteki, 2009; Gulsoy and Eroglu, 2011; Gümüşkaya et al., 2011).

The effect of $\mathrm{NaBH}_{4}$ and $\mathrm{KBH}_{4}$ additions on burst index of handsheets is given in Figure 5. Burst index increased with $\mathrm{NaBH}_{4}$ and $\mathrm{KBH}_{4}$ additions except for $1 \% \mathrm{KBH}_{4}$ added pulp $(p<0.05)$. The highest burst index was determined in $0.5 \% \mathrm{KBH}_{4}$ added pulp with $3.27 \mathrm{kPa} \cdot \mathrm{m}^{2} / \mathrm{g}$. Burst index of European black pine kraft pulp (Gulsoy and Eroglu, 2011) and stone pine AS-AQ pulp (Gümüşkaya et al., 2011) increased with $1 \% \mathrm{NaBH}_{4}$ addition. On the contrary, Çöpür and Tozluoğlu (2008) noted in Brutia pine kraft pulp and Istek and Gonteki (2009) in maritime pine that $\mathrm{NaBH}_{4}$ had a negative effect on burst index of handsheets.

The effect of $\mathrm{NaBH}_{4}$ and $\mathrm{KBH}_{4}$ additions on brightness of handsheets is given in Figure 6. Brightness increased with $\mathrm{NaBH}_{4}$ and $\mathrm{KBH}_{4}$ additions $(p<0.05)$. This result can be attributed to lower kappa number of $\mathrm{NaBH}_{4}$ and $\mathrm{KBH}_{4}$ added pulps than that of control pulp (Table 3). The highest brightness was determined in $2 \% \mathrm{KBH}_{4}$ added pulp with $20.16 \%$. Similar brightness increases were reported in earlier studies (Akgül et al., 2007; Çöpür and Tozluoğlu, 2008; Istek and Gonteki, 2009; Gulsoy and Eroglu, 2011).

\section{CONCLUSIONS}

\section{ZAKLJUČAK}

Chemical composition analysis showed that bracken stalks had higher holocellulose and lignin, and lower $\alpha$-cellulose content than those of other lignocel-



Figure 4 Effect of $\mathrm{NaBH}_{4}$ and $\mathrm{KBH}_{4}$ additions on tear index of handsheets Slika 4. Utjecaj dodavanja $\mathrm{NaBH}_{4}$ i $\mathrm{KBH}_{4}$ na indeks cijepanja uzoraka papira

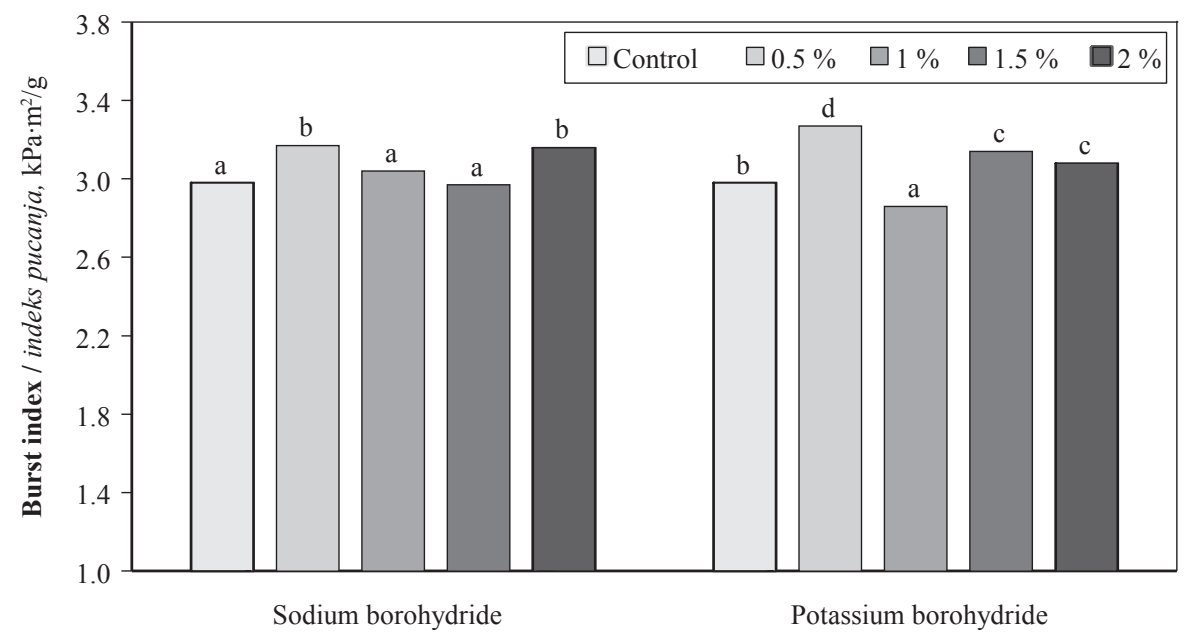

Figure 5 Effect of $\mathrm{NaBH}_{4}$ and $\mathrm{KBH}_{4}$ additions on burst index of handsheets Slika 5. Utjecaj dodavanja $\mathrm{NaBH}_{4}$ i $\mathrm{KBH}_{4}$ na indeks pucanja uzoraka papira 


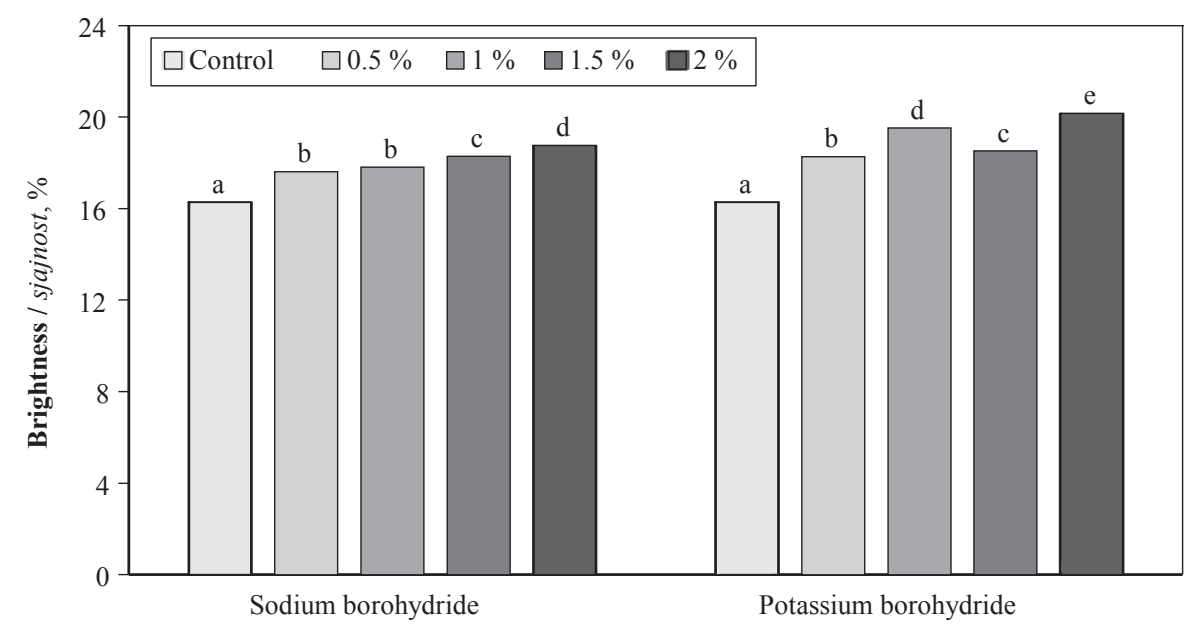

Figure 6 Effect of $\mathrm{NaBH}_{4}$ and $\mathrm{KBH}_{4}$ additions on handsheet brightness Slika 6. Utjecaj dodavanja $\mathrm{NaBH}_{4}$ i $\mathrm{KBH}_{4}$ na sjajnost uzoraka papira

lulosic nonwood resources. The fiber properties of bracken stalks were similar to the fibers of other nonwood resources and aspen. Kraft pulp properties of bracken stalks were determined to be comparable with those of hardwoods (aspen and eucalyptus) and common nonwood papermaking raw materials. $\mathrm{NaBH}_{4}$ and $\mathrm{KBH}_{4}$ additions caused the increase of pulp yield and decrease of kappa number. Also, strength properties of bracken stalks kraft pulp increased with $\mathrm{NaBH}_{4}$ and $\mathrm{KBH}_{4}$ additions except for tear index. $\mathrm{NaBH}_{4}$ and $\mathrm{KBH}_{4}$ had a positive effect on pulp brightness. Consequently, the bracken stalks can be used as a fiber source for paper production.

\section{Acknowledgements - Zahvala}

This paper was supported by Bartin University Scientific Research Project Commission (Project number: BAP-FEN-A-002).

\section{REFERENCES}

\section{LITERATURA}

1. Agnihotri, S.; Dutt, D.; Tyagi, C. H., 2010: Complete characterization of bagasse of early species of Saccharum officinerum-CO 89003 for pulp and paper making. BioResources, 5 (2): 1197-1214.

2. Akgül, A.; Temiz, S., 2006: Determination of kraft$\mathrm{NaBH}_{4}$ pulping condition of Uludağ fir (Abies bornmulleriana Mattf.). Pakistan Journal of Biological Sciences, 9 (13): 2493-2497. https://doi.org/10.3923/pjbs.2006.2493.2497

3. Akgül, M.; Çöpür, Y.; Temiz, S. A., 2007: Comparison of kraft and kraft sodium borohydrate brutia pine pulps. Building and Environment, 42 (7): 2586-2590. https://doi.org/10.1016/j.buildenv.2006.07.022.

4. Akgül, M.; Tozluoğlu, A., 2009: A comparison of soda and soda-AQ pulps from cotton stalks. African Journal of Biotechnology, 8: 6127-6133. https://doi.org/10.5897/AJB09.301

5. Albert, S.; Padhiar, A.; Gandhi, D., 2011: Fiber Properties of Sorghum halepense and its suitability for paper production. Journal of Natural Fibers, 8: 263-271. https://doi.org/10.1080/15440478.2011.626236.
6. Ates, S.; Ni, Y.; Akgul, M.; Tozluoglu, A., 2008: Characterization and evaluation of Paulownia elongota as a raw material for paper production. African Journal of Biotechnology, 7 (22): 4153-4158.

7. Ateş, S.; Deniz, İ.; Kirci, H.; Atik, C.; Okan, O. T., 2015: Comparison of pulping and bleaching behaviors of some agricultural residues. Turkish Journal of Agriculture and Forestry, 39: 144-153.

https://doi.org/10.3906/tar-1403-41.

8. Berlyn, G. P.; Miksche, J. P., 1976: Botanical Microtechnique and Cytochemistry. Ames, IA: Iowa State University Press.

9. Çöpür, Y.; Tozluoğlu, A.; Karademir, A., 2007: Pulping of Licorice (Glycyrrhiza glabra): An alternative raw material to produce pulp. Cellulose Chemistry and Technology, 41: 155-159.

10. Çöpür, Y.; Tozluoğlu, A., 2008: A comparison of kraft, PS, kraft-AQ and kraft-NaBH $\mathrm{N}_{4}$ pulps of Brutia pine. Bioresource Technology, 99: 909-913. https://doi.org/10.1016/j.biortech.2007.04.015.

11. Deniz, İ.; Kırc1, H.; Ateş, S., 2004: Optimization of wheat straw (Tiriticum durum) kraft pulping. Industrial Crops and Products, 19: 237-243. https://doi.org/10.1016/j.indcrop.2003.10.011.

12. Dutt, D.; Upadhyaya, J. S.; Tyagi, C. H.; Kumar, A.; Lal, M., 2008: Studies on Ipomea carnea and Cannabis sativa as an alternative pulp blend for softwood: An optimization of kraft delignification process. Industrial Crops and Products, 28: 128-136. https://doi.org/10.1016/j.indcrop.2008.02.001.

13. Dutt, D.; Upadhyaya, J. S.; Singh, B.; Tyagi, C. H., 2009: Studies on Hibiscus cannabinus and Hibiscus sabdariffa as an alternative pulp blend for softwood: An optimization of kraft delignification process. Industrial Crops and Products, 29: 16-26. https://doi.org/10.1016/j.indcrop.2008.03.005.

14. Dutt, D.; Tyagi, C. H., 2011: Comparison of various eucalyptus species for their morphological, chemical, pulp and paper making characteristics. Indian Journal of Chemical Technology, 18: 145-151.

15. Enayati, A. A.; Hamzeh, Y.; Mirshokraie, S. A.; Molaii, M., 2009: Papermaking potential of canola stalks. BioResources, 4 (1): 245-256.

16. Erişir, E.; Gümüşkaya, E.; Kirci, H.; Misir, N., 2015: Alkaline sulphite pulping of Caucasian spruce (Picea orien- 
talis L.) chips with additions of $\mathrm{NaBH}_{4}$ and ethanol. Drewno, 58 (194): 89-102.

http://dx.doi.org/10.12841/wood.1644-3985.067.07.

17. FAOSTAT, 2016: Food and Agriculture Organization Statistics, Rome, Italy.

18. Gellerstedt, G., 2010. Chemistry of Pulp Bleaching. Chapter 11 in: Lignin and Lignans: Advances in Chemistry. Edited by Heitner, C., Dimmel, D. R., Schmidt, J. A. pp. 393-438. https://doi.org/10.1201/EBK1574444865-c11

19. Gençer, A.; Şirin, G.; Gül, H.; Özgül, U., 2013: Determination of the product conditions of pulp and paper from white mulberry (Morus alba L.) by kraft method. Journal of Bartin Faculty of Forestry, 15 (1-2): 63-68.

20. Gençer, A., 2015: Research on the suitability of broomcorn stalks for paper production and the effects of hotwater pre-treatment on paper's properties. Journal of Multidisciplinary Engineering Science and Technology, 2 (8): 2089-2092.

21. Gençer, A.; Şahin, M., 2015: Identifying the conditions required for the $\mathrm{NaOH}$ method for producing pulp and paper from sorghum grown in Turkey. BioResources, 10 (2): $2850-2858$. https://doi.org/10.15376/biores.10.2.2850-2858

22. Gençer, A.; Gül Türkmen, H., 2016: Determination of paper production conditions of wild cherry heartwood and sapwood. Journal of Bartin Faculty of Forestry, 18 (1): 23-31.

23. Gençer, A.; Özgül, U., 2016: Utilization of common hazelnut (Corylus avellana L.) prunings for pulp production. Drvna industrija, 67 (2): 157-162. https://doi.org/10.5552/drind.2016.1529.

24. Gominho, J.; Fernandez, J.; Pereira, H., 2001: Cynara cardunculus L. - a new fibre crop for pulp and paper production. Industrial Crops and Products, 13: 1-10. https://doi.org/10.1016/S0926-6690(00)00044-3.

25. González, Z.; Rosal, A.; Requejo, A.; Rodríguez, A., 2011: Production of pulp and energy using orange tree prunings. Bioresource Technology, 102: 9330-9334. https://doi.org/10.1016/j.biortech.2011.07.088.

26. Goswami, T.; Kalita, D.; Rao, P. G., 2008: Greaseproof paper from Banana (Musa paradisica L.) pulp fibre. Indian Journal of Chemical Technology, 15 (5): 457-461.

27. Gulsoy, S. K.; Eroglu, H., 2011: Influence of sodium borohydride on kraft pulping of European black pine as a digester additive. Industrial \& Engineering Chemistry Research, 50 (4): 2441-2444. https://doi.org/10.1021/ie101999p.

28. Gulsoy, S. K.; Tufek, S., 2013: Effect of chip mixing ratio of Pinus pinaster and Populus tremula on kraft pulp and paper properties. Industrial \& Engineering Chemistry Research, 52 (6): 2304-2308. https://doi.org/10.1021/ie302709e.

29. Gülsoy, S. K.; Kılıç Pekgözlü, A.; Aktaş, A. C., 2015: Utilization of the pomegranate tree (Punica granatum L.) in the paper industry. Turkish Journal of Agriculture and Forestry, 39: 295-299. https://doi.org/10.3906/tar-1404-105.

30. Gülsoy, S. K.; Oğuz, S.; Uysal, S.; Şimşir, S.; Taş, M., 2016: The influence of potassium borohydride $\left(\mathrm{KBH}_{4}\right)$ on kraft pulp properties of maritime pine. Journal of Bartin Faculty of Forestry, 18 (2): 103-106. https://doi.org/10.24011/barofd.267296.

31. Gümüşkaya, E.; Usta, M., 2006: Dependence of chemical and crystalline structure of alkali sulfite pulp on cooking temperature and time. Carbohydrate Polymers, 65 (4): 461-468. https://doi.org/10.1016/j.carbpol.2006.02.004.

32. Gümüşkaya, E.; Erişir, E.; Kirci, H.; Misir, N., 2011: The effect of sodium borohydride on alkaline sulfite-anthraquinone pulping of pine (Pinus pinea) wood. Industrial \& Engineering Chemistry Research, 50 (13): 8340-8343. https://doi.org/10.1021/ie200633z.

33. Han, J. S.; Rowell, J. S., 1997: Chemical Composition of Agrobased Fibers, Chapter 5. In: Rowell, R. M., Young, R. A., Rowell, J. K. (eds.) Paper and Composites from Agrobased Resources, CRC Press Inc., New York, 83$134 \mathrm{pp}$.

34. Hemmasi, A. H.; Samariha, A.; Tabei, A.; Nemati, M.; Khakifirooz, A., 2011: Study of morphological and chemical composition of fibers from Iranian sugarcane bagasse. American-Eurasian Journal of Agricultural \& Environmental Sciences, 11 (4): 478-481.

35. Istek, A.; Özkan, I., 2008: Effect of sodium borohydride on Populus tremula L. kraft pulping. Turkish Journal of Agriculture and Forestry, 32: 131-136.

36. Istek, A.; Gonteki, E., 2009: Utilization of sodium borohydride $\left(\mathrm{NaBH}_{4}\right)$ in kraft pulping process. Journal of Environmental Biology, 30 (6): 951-953. https://doi.org/10.1016/j.indcrop.2005.05.001.

37. Jiménez, L.; Rodríguez, A.; Pérez, A.; Moral, A.; Serrano, L., 2008: Alternative raw materials and pulping process using clean technologies. Industrial Crops and Products, 28: 11-16. https://doi.org/10.1016/j.indcrop.2007.12.005.

38. Kamthai, S.; Puthson, P., 2005: Effect of beating revolution on sweet bamboo (Dendrocalamus asper Backer) kraft pulp properties. CMU Journal, 4 (2): 137-147.

39. Kasmani, J. E.; Samariha, A., 2011: Some chemical and morphological properties of wheat straw. Middle-East Journal of Scientific Research, 8 (4): 823-825.

40. Khristova, P.; Kordsachia, O.; Patt, R.; Dafaalla, S., 2006: Alkaline pulping of some eucalyptus from Sudan. Bioresource Technology, 97 (4): 535-544. https://doi.org/10.1016/j.biortech.2005.04.006.

41. Kiaei, M., 2014: Investigation on biometrical properties and mineral content of rice residues and its application in pulp and paper production. Advances in Environmental Biology, 8 (13): 952-959.

42. López, F.; Eugenio, M. E.; Díaz, M. J.; Nacimiento, J. A.; García, M. M.; Jiménez, L., 2005: Soda pulping of sunflower stalks. Influence of process variables on the resulting pulp. Journal of Industrial and Engineering Chemistry, 11 (3): 387-394.

43. Madakadze, I. C.; Radiotis, T.; Li, J.; Goel, K.; Smith, D. L., 1999: Kraft pulping characteristics and pulp properties of warm season grasses. Bioresource Technology, 69 (1): 75-85. https://doi.org/10.1016/S0960-8524(98)00131-X.

44. Moradbak, A.; Tahir, P. Md.; Mohamed, A. Z.; Halis, R. B., 2016: Alkaline sulfite anthraquinone and methanol pulping of bamboo (Gigantochloa scortechinii). BioResources, 11 (1): 235-248.

45. Omotoso, M. A.; Owolabi, A. W., 2015: Pulp and paper evaluation of solid wastes from agricultural produce. International Journal of Chemistry, 7 (2): 113-121. https://doi.org/10.5539/ijc.v7n2p113.

46. Requejo, A.; Rodríguez, A.; Colodette, J. L.; Gomide, J. L.; Jimenéz, L., 2012: TCF bleaching sequence in kraft pulping of olive tree prunings. Bioresource Technology, 117: $117-123$

https://doi.org/10.1016/j.biortech.2012.04.084.

47. Saraçbaş1, A.; Şahin, H.T.; Karademir, A., 2016: Effects of sodium borohydride addition to kraft pulping process 
of some pine species. Journal of Forestry Research, 1 (4): 134-143. http://dx.doi.org/10.17568/oad.19661.

48. Shakhes, J.; Marandi, M. A. B.; Zeinaly, F.; Saraian, A.; Saghafi, T., 2011: Tobacco residuals as promising lignocellulosic materials for pulp and paper industry. BioResources, 6 (1): 4481-4493.

49. Shatalov, A. A.; Pereira, H., 2006: Papermaking fibers from giant reed (Arundo donax L.) by advanced ecologically friendly pulping and bleaching technologies. BioResources, 1: 45-61.

50. Spearin, W. E.; Isenberg, I. H., 1947: Maceration of woody tissue with acetic acid and sodium chlorite. Science, 105: 214-214. https://doi.org/10.1126/science.105.2721.214.

51. Tofanica, B. M.; Cappelletto, E.; Gavrilescu, D.; Mueller, K., 2011: Properties of rapeseed (Brassica napus) stalks fibers. Journal of Natural Fibers, 8: 241-262. https://doi.org/10.1080/15440478.2011.626189.

52. Tutus, A.; Deniz, I.; Eroglu, H., 2004: Rice straw pulping with oxide added soda-oxygen-anthraquinone. Pakistan Journal of Biological Sciences, 7 (8): 1350-1354. https:// doi.org/10.3923/pjbs.2004.1350.1354

53. Tutus, A.; Ates, S.; Deniz, I., 2010a: Pulp and paper production from Spruce wood with kraft and modified kraft methods. African Journal of Biotechnology, 9 (11): 16481654. https://doi.org/10.5897/AJB10.1906

54. Tutus, A.; Ezici, A. C.; Ates, S., 2010b: Chemical, morphological and anatomical properties and evaluation of cotton stalks (Gossypium hirsutum L.) in pulp industry. Scientific Research and Essays, 5 (12): 1553-1560.

55. Tye, Y. Y.; Lee, K. T.; Abdullah, W. N. W. A.; Leh, C. P., 2016: The world availability of non-wood lignocellulosic biomass for the production of cellulosic ethanol and potential pretreatments for the enhancement of enzymatic saccharification. Renewable and Sustainable Energy Reviews, 60: 155-172. https://doi.org/10.1016/j.rser.2016.01.072.

56. Usta, M.; Eroglu, H., 1988: Soda-Oxygen Pulping of Rye Straw, Nonwood Plant Fiber Pulping, Progress Report No: 18, TAPPI Press, Atlanta, USA, pp. 113-118.
57. Usta, M.; Kırc1, H.; Eroglu, H., 1990: Soda-Oxygen Pulping from corn (Zeamays indurate Sturt). Tappi Pulping Conference, Toronto, Ontario, Canada, Proceeding Book 1, pp. 307-312.

58. Ververis, C.; Georghiou, K.; Christodoulakis, N.; Santas, P.; Santas, R., 2004: Fiber dimensions, lignin and cellulose content of various plant materials and their suitability for paper production. Industrial Crops and Products, 19: $245-254$. https://doi.org/10.1016/j.indcrop.2003.10.006.

59. Vetter, J., 2009: A biological hazard of our age: bracken fern [Pteridium aquilinum (L.) Kuhn] - A review. Acta Veterinaria Hungarica, 57 (1): 183-196. https://doi.org/10.1556/AVet.57.2009.1.18.

60. Wise, L. E.; Karl, H. L., 1962: Cellulose and Hemicellulose in Pulp and Paper Science and Technology. New York: McGraw Hill Book Co.

61. Xu, F.; Zhong, X. C.; Sun, R. C.; Lu, Q., 2006: Anatomical ultrastructure and lignin distribution in cell wall of Caragana korshinskii. Industrial Crops and Products, 24 (2): 186-193. https://doi.org/10.1016/j.indcrop.2006.04.002.

62. Zhu, J. Y.; Pan, X. J., 2010: Woody biomass pretreatment for cellulosic ethanol production: technology and energy consumption evaluation. Bioresource Technology, 101 (13): 4992-5002.

https://doi.org/10.1016/j.biortech.2009.11.007.

\section{Corresponding address:}

Assoc. Prof. SEZGIN KORAY GÜLSOY, Ph.D.

Faculty of Forestry, Forest Products Engineering Bartin University

Bartin, TURKEY

e-mail: sgulsoy@bartin.edu.tr szgngulsoy@yahoo.com 